\title{
Pointing on the early stages of maxillary bone and tooth development - histological findings
}

\author{
Radu Brăescu1) , Sergiu Daniel Săvinescu2), Monica Silvia Tatarciuc ${ }^{1)}$, Irina Nicoleta Zetu³), \\ SimONA ELIZA GIUŞCĂ ${ }^{4}$, IRINA-DRAGA CĂRUNTU4)
}

\begin{abstract}
1) Department of Technology of Dental Prosthesis, Grigore T. Popa University of Medicine and Pharmacy, Iaşi, Romania
2) County Service of Forensic Medicine, Emergency County Hospital, Vaslui, Romania

3) Department of Orthodontics and Dento-facial Orthopedics, Grigore T. Popa University of Medicine and Pharmacy, Iaşi, Romania
\end{abstract}

4) Department of Morphofunctional Sciences I, Grigore T. Popa University of Medicine and Pharmacy, Iaşi, Romania

\begin{abstract}
Although the morphological stages of tooth development, in parallel with maxillary bone construction, are known for decades, the intimate mechanisms of early development of the oral cavity structures and tooth's proper and associated tissues are still incompletely elucidated. Nowadays, the research in embryology was shifted from the morphological to the molecular and genetic approach. This new approach is accomplished by using in vivo and in vitro experimental studies performed on animal models and cell lines. The interest in the knowledge of these events at gene and molecular level is still current, aiming to sustain the progress in the endorsement of novel regenerative and restorative therapies. However, the morphological standpoint maintains its interest, because the extrapolation of the results of experimental studies in humans requires a strong confirmation. Within this context, our work aims to analyze the histological characteristics of the maxillary bone and integrated tooth germs during the early stages of embryonic development. The study group consisted in mandible fragments obtained by dissection of the cephalic extremities collected from fetuses aged from 10 to 24 weeks, after medical or spontaneous abortions. The tissue specimens were processed for the histological exam. The histoarchitectonic traits of the initial stages of mandibular bone tissue and tooth development were assessed. The results revealed the dynamics of the ossification stages, from stages of early-dispersed intramembranous ossification to the organization of the dental alveoli, incorporated step-by-step in the maxillary body, and the simultaneous presence of tooth germs with different sizes and shapes, in accordance with the development stage. Our study complements the existing data regarding the embryonic period, bringing an important contribution for the enlargement of existing morphological, visual information for maxillary bone and tooth development.
\end{abstract}

Keywords: maxillary bone, tooth germ, development, histology.

\section{口 Introduction}

The morphogenesis of the maxillary bone and tooth is implicitly integrated in the embryological development of the individual, in direct correlation with the formation of the cephalic extremity. Classical data given in embryological, anatomical and histological course books are constantly updated by the research focused on these topics, published in the mainstream. However, the intimate mechanisms of early development of the oral cavity structures (in general), and of the tooth's proper and associated tissues (in particular) are still incompletely elucidated.

The development of jaw cannot be separated from the tooth development, due to their common origin in the first pharyngeal arch and their structural interdependency [15]. The pharyngeal arches are transient structures with a deciding role in the embryo-fetal development of head and neck. The first pharyngeal arch is divided into the maxillary process (cranial) and mandibular process (caudal) which will contain the Meckel's cartilage [6, 7]. Premaxillary, maxillary, zygomatic bone, and part of the temporal bone are developed from the maxillary process, whereas mandible - from the mandibular process [6, 7]. Migration of the cells of neural crests is a critical event, ensuring the formation of the ectomesenchymal tissue necessary for the craniofacial evolution $[2,4,6,7]$.

The growth of the maxillary and mandibular processes, approximately in the $6^{\text {th }}$ week of development, leads to the narrowing of the primitive oral cavity, named stomodeum. The stomodeal epithelium begins to proliferate, forming the odontogenic epithelium $[6,7]$. On the $37^{\text {th }}$ day of development, two continuous, thick epithelial bands appear on the site of the future dental arches, and each band is rapidly subdivided into a vestibular lamina and a dental lamina $[6,7]$. In the underlying ectomesenchyme, the vestibular lamina creates a free space that is the oral vestibule $[6,7]$. The dental lamina presents several areas of proliferative activity, recognizable in the regions of the future alveolar processes as epithelial outgrowths oriented inwards, towards ectomesenchyme [6, 7]. The epithelial outgrowths, called epithelial bud [6], are separated from the mesenchymal/ectomemesenchymal cells by a distinct basal membrane. Thus, in the 6-8 weeks of development, on the places corresponding to the future deciduous teeth, 20 tooth germs are formed [6]. In the following period, the 32 tooth germs for permanent dentition will also appear [6]. The histological components specific to the tooth should be integrated in the structure of the maxillary bone through the architecture of the deep

This is an open-access article distributed under the terms of a Creative Commons Attribution-NonCommercial-ShareAlike 4.0 International Public License, which permits unrestricted use, adaptation, distribution and reproduction in any medium, non-commercially, provided the new creations are licensed under identical terms as the original work and the original work is properly cited. 
periodontium $[1,6]$. The result is a unique, individual morphological system that brings together epithelial and connective tissue components in specific variants.

Odontogenesis occurs due to a sequence of processes whose coordination, at a molecular level, is reflected in the events that determine morphogenesis, histogenesis and cell differentiation $[1,4,6,8]$ of the tooth germs. In parallel, tooth and supporting tissue regional development involves a phenomenon of spatiotemporal modeling, based on the existing interrelationship of the induction-competence sequence $[1,4,6,8]$. Although tooth development stages and phases are succeeding dynamically, the strict delimitation of one stage from another is practically impossible; moreover, at certain times, there is a partial superposition [6].

Nowadays, the research in embryology was shifted from the morphological to the molecular and genetic approach. This new approach is accomplished by using in vivo and in vitro experimental studies performed on animal models and cell lines. However, the morphological standpoint maintains its interest, because the extrapolation of the results of experimental studies in humans requires a strong confirmation. Within this context, our study is justified by the small number of recent papers that report data on microscopic embryological research in humans - research burdened by current ethical restrictions and, concomitantly, by technical difficulties.

Our interest in the investigation of the maxillary bone and tooth development is part of the general knowledge drive, adding informative value and completing our previous reports on dental histology [9-12].

\section{Aim}

The study aims to analyze the histological characteristics of the maxillary bone and integrated tooth germs during the early stages of embryonic development.

\section{ㅁ Materials and Methods}

The analyzed material consists in tissue fragments of mandibles obtained by dissection of the cephalic extremities collected from fetuses aged from 10, 14, 18, 22 and 24 weeks, after medical or spontaneous abortions. The necropsy was done at Vaslui County Forensic Service and Laboratory

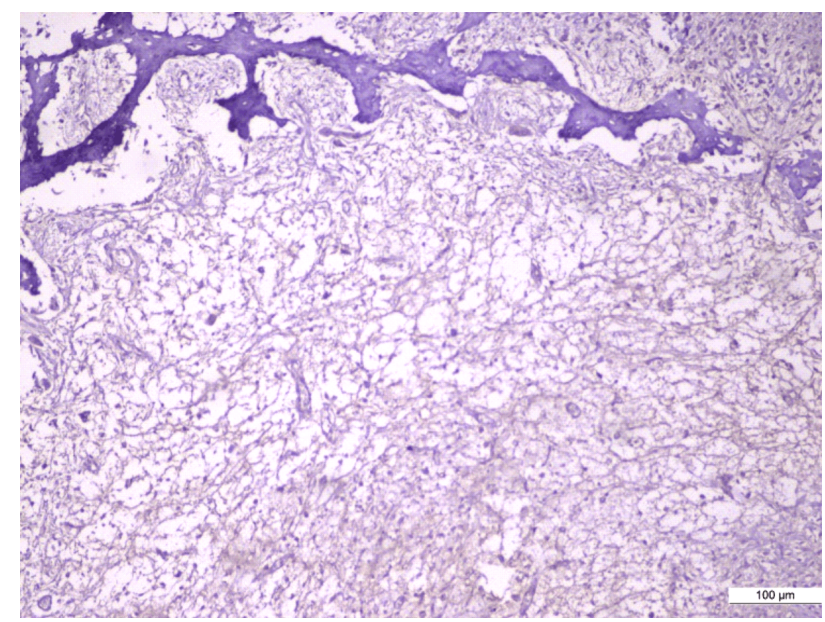

Figure 1 - Embryonic bone trabeculae within the mesenchymal tissue (HE staining, ×100). of Pathology, Municipal Hospital of Bârlad, Romania. The legal conditions for harvesting, handling and conservation of embryonic human material were respected, based on the written consent of the family, certified by an informed consent protocol. The study was approved by the Ethics Committee of the Grigore T. Popa University of Medicine and Pharmacy, Iaşi, Romania (Ethics Agreement No. 1/ 13.10.2009), in accordance with the Helsinki Declaration. The tissue specimens were decalcified (between three days and three weeks) and processed for paraffin-embedding technique. The paraffin blocks were sectioned at $4 \mu \mathrm{m}$. The sections were stained with Hematoxylin-Eosin (HE) for standard histological examination, as well as with special stainings [Masson's trichrome, Szekely trichrome, Periodic Acid-Schiff (PAS)]. The microscopic assessment aimed the identification and characterization of histological and histoarchitectonic elements of the initial stages of mandibular bone tissue and tooth development.

\section{口 Results}

The microscopic exam showed morphological traits that correspond to the dynamics of the ossification stages, from stages of early dispersed intramembranous ossification to the organization of the dental alveoli, incorporated stepby-step in the mandibular body.

In the mesenchymal tissue, we identified elements specific to the formation of the embryonic bone with nonlamellar fascicular histology. Mesenchymal cell proliferation and condensation resulted in the formation of bone spicules growing by fusion into thin bone plates or trabeculae covered on their outer surface by osteoblasts and on the inner layer by osteocytes. The embryonic bone trabeculae were initially separated by mesenchymal tissue (Figure 1), later developing large, areolar spaces occupied by connective tissue and blood vessels (Figures 2 and 3). Microscopic analysis revealed the particular structure of the embryonic bone, due to the young rough collagen fibers oriented randomly and crosswise, rich in cells (Figures 4-6).

The microscopic exam revealed tooth germs corresponding to incisors 1 and 2, canine, molars 1 and 2 in various development stages, located in the forming mandibular structures in relation to the gestational age (Table 1).

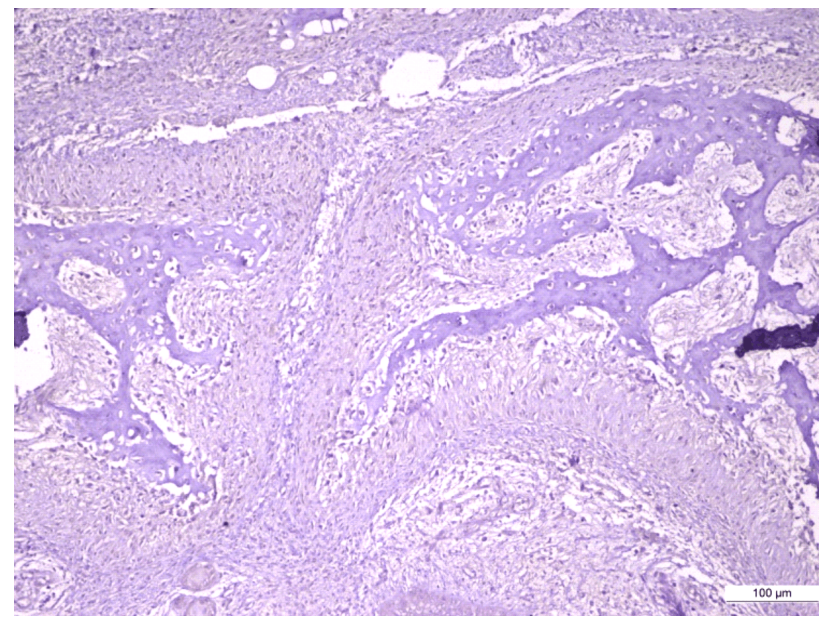

Figure 2 - Anastomosed embryonic bone trabeculae separated by areolar spaces (HE staining, $\times 100)$. 


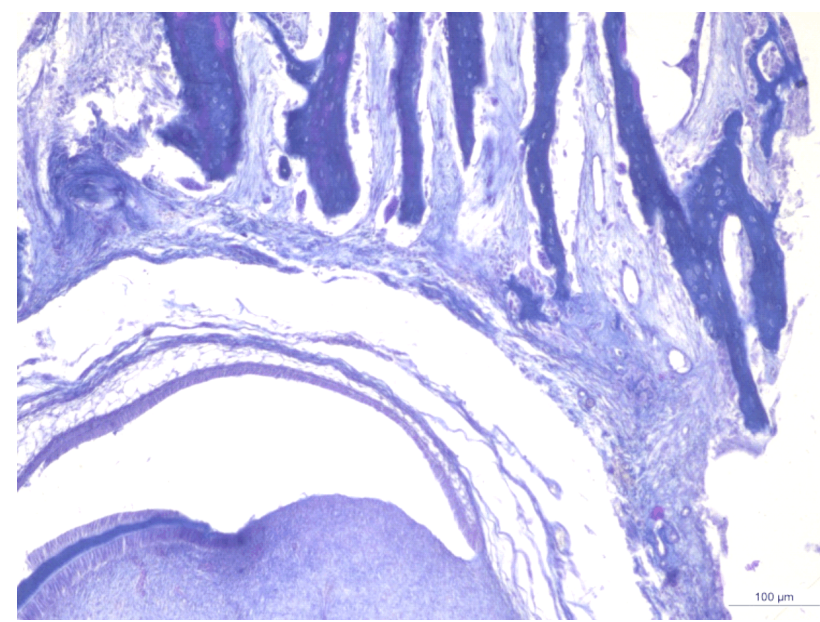

Figure 3 - Embryonic bone trabeculae adjacent to a tooth germ (Masson's trichrome staining, $\times 100$ ).

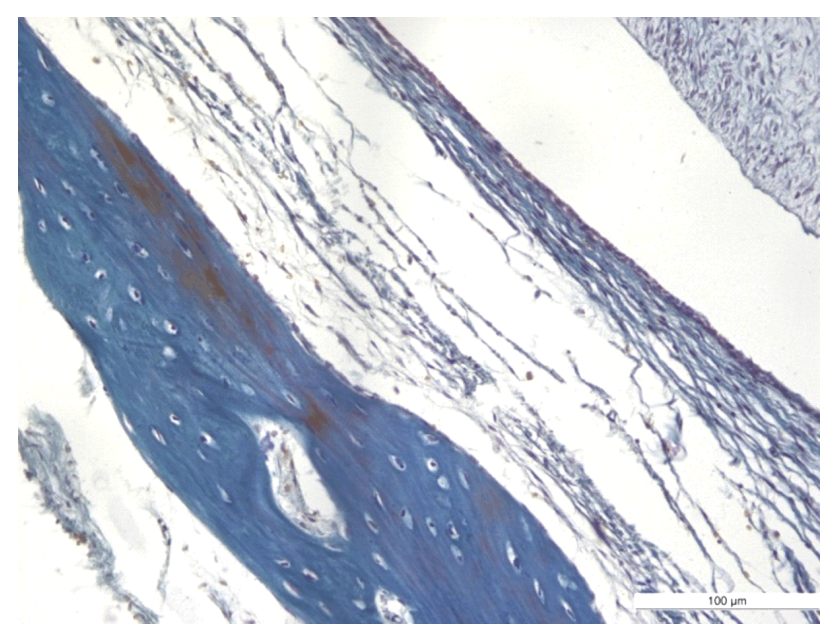

Figure 5 - Dental sac area in continuity with embryonic bone (Masson's trichrome staining, $\times 200$ ).

Table 1 - Development stages of tooth germs

\begin{tabular}{|c|c|c|c|c|c|c|}
\hline \multirow{2}{*}{$\begin{array}{l}\text { Case } \\
\text { No. }\end{array}$} & \multirow{2}{*}{$\begin{array}{c}\text { Development } \\
\text { age [weeks] }\end{array}$} & \multicolumn{5}{|c|}{ Tooth - development stages } \\
\hline & & Incisor $_{1}$ & Incisor $_{2}$ & Canine & Molar $_{1}$ & Molar $_{2}$ \\
\hline 1. & 10 & cap & cap & cap & cap & absent \\
\hline 2. & 14 & $\begin{array}{l}\text { early } \\
\text { bell }\end{array}$ & cap & cap & cap & absent \\
\hline 3. & 18 & $\begin{array}{l}\text { late } \\
\text { bell }\end{array}$ & $\begin{array}{l}\text { early } \\
\text { bell }\end{array}$ & $\begin{array}{l}\text { early } \\
\text { bell }\end{array}$ & cap & cap \\
\hline 4. & 22 & $\begin{array}{l}\text { late } \\
\text { bell }\end{array}$ & $\begin{array}{l}\text { late } \\
\text { bell }\end{array}$ & $\begin{array}{l}\text { late } \\
\text { bell }\end{array}$ & $\begin{array}{l}\text { late } \\
\text { bell }\end{array}$ & $\begin{array}{c}\text { early } \\
\text { bell }\end{array}$ \\
\hline 5. & 24 & $\begin{array}{l}\text { late } \\
\text { bell }\end{array}$ & $\begin{array}{l}\text { late } \\
\text { bell }\end{array}$ & $\begin{array}{l}\text { late } \\
\text { bell }\end{array}$ & $\begin{array}{l}\text { late } \\
\text { bell }\end{array}$ & $\begin{array}{l}\text { late } \\
\text { bell }\end{array}$ \\
\hline
\end{tabular}

The tooth germs in cap stage showed the morphological components characteristic to this development stage: an enamel organ, a dental papilla with mesenchymal and ectomesenchymal cells and a loose dental sac. Adjacent, we noted morphological elements specific to the early moments of the dental alveoli formation in the mandibular body, namely very thin walls of the crypts, with "eggshell” appearance (Figure 7).

Progressive events occurring during the transition from cap stage to early bell stage were reflected by the crowding tendency of ectomesenchymal and mesenchymal

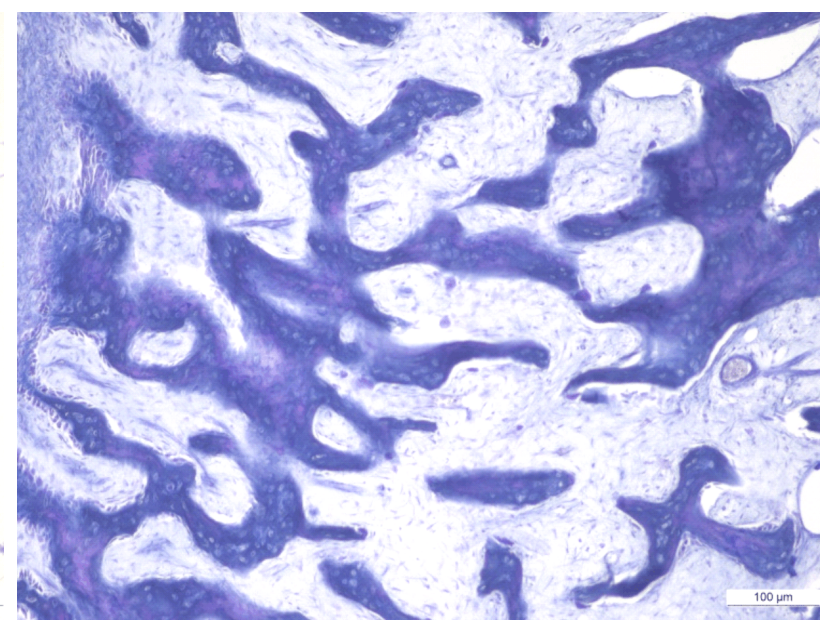

Figure 4 - Embryonic bone trabeculae with different degrees of mineralization (Masson's trichrome staining, $\times 100$ ).

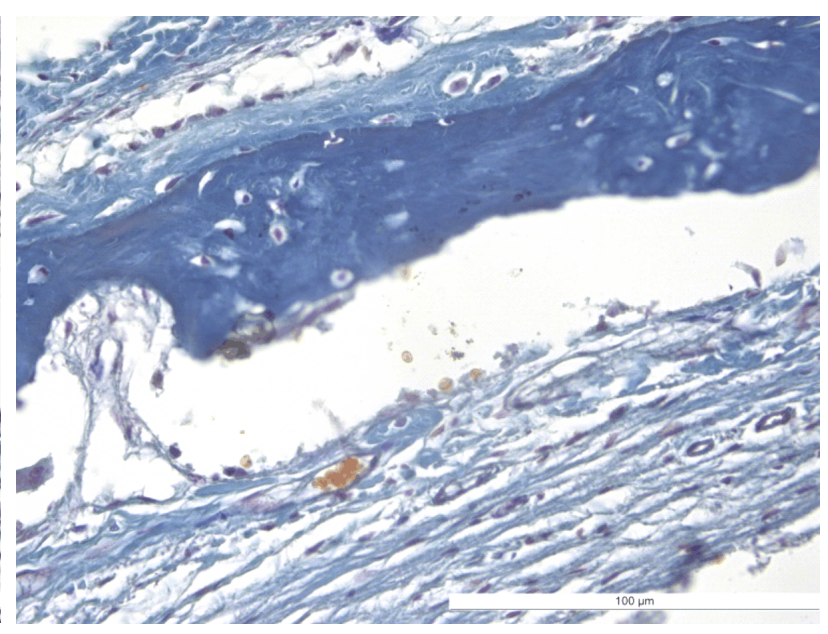

Figure 6 - Embryonic bone lined by osteoblasts, containing numerous active osteocytes among the collagen fibers, partially mineralized (Masson's trichrome staining, $\times 400)$.

cells near the basal membrane of the inner epithelium, resulting in the successive formation of preodontoblasts and odontoblasts that induce and complete the emergence of ameloblasts (Figure 8).

The tooth germs in later bell stage showed all the histological traits characteristic to that development stage, such as enamel and dentin synthesis in variable amounts (Figures 9-10). The dental sac was denser because of cell maturity. Around the dental germs in the bell stage, the forming crypt had larger sizes, reflecting bone deposits on the inner edge. Due to the low gestational age of the cases included in the study group, the initial phase of root formation was not noticed. Therefore, the obvious histological elements that support the initiation of cementum and periodontal ligament formation were absent.

\section{Discussions}

The first studies on the development of maxillary bone and tooth, as part of embryonic human development, are published in the late $19^{\text {th }}$ and early $20^{\text {th }}$ centuries [13-24]. The theoretical substrate of knowledge is founded on morphological studies of normal craniofacial development [4]. 


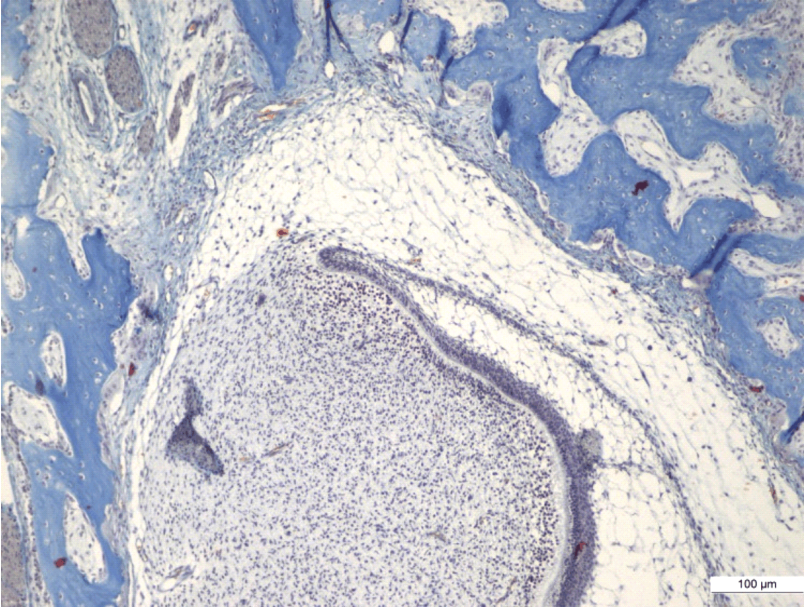

Figure 7 - Tooth germ: cap stage surrounded by the dental sac and developing embryonic bone of the mandible (Masson's trichrome staining, $\times 100$ ).

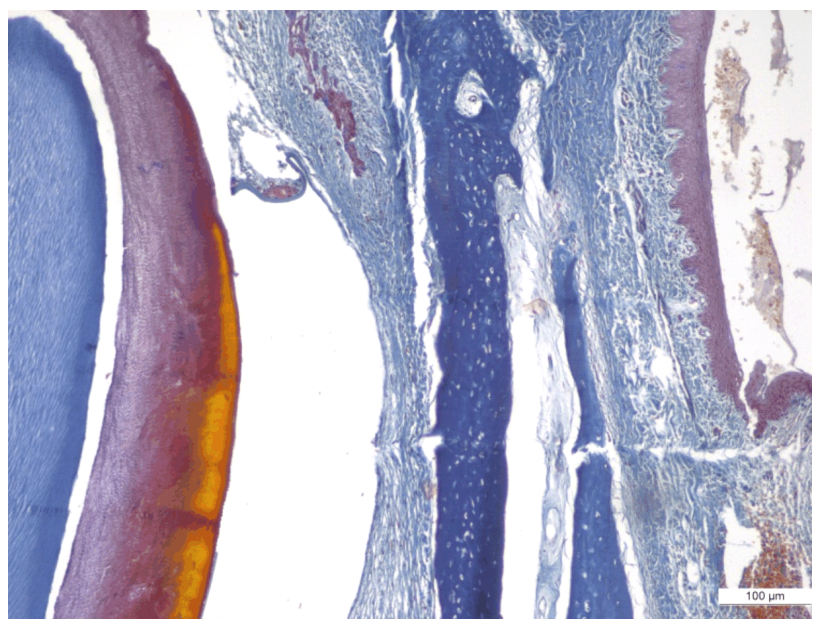

Figure 9 - Tooth germ: advanced bell stage, separated by the dental sac from the maxillary embryonic bone; stomodeal epithelium on the surface (Masson's trichrome staining, $\times 100$ ).

Since the ' 80 s, important contributions in this field were brought by the studies on human embryos performed by Merida Velasco's and Radlanski's groups. Merida Velasco's group reports focuses on the development of the mandibulae and proves details on the role of Meckel's cartilage and the differences in the ossification process of the mandibular corpus and ramus [25-27]; another issue addressed is the tooth development, pointing on the evolution of the dental crest and the growth of first molars $[28,29]$. The relationship between Meckel's cartilage and the morphogenesis of the mandible was also investigated by other groups of researchers [30-32]. By using the computer-assisted facilities, Radlanski's groups work is based on three and four-dimensional reconstruction of embryological structures from histological serial sections of human embryos which belong to the valuable Radlanski's collection, Charité - Berlin University of Medicine [33-38]. Relying on the analysis of digitized images of the microscopic structures, associated with radiological and cephalometric evaluations, the results

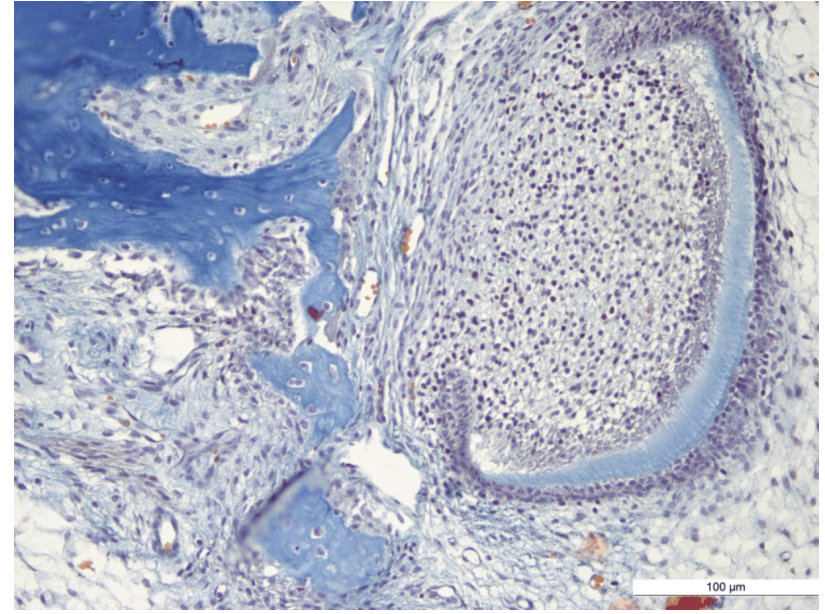

Figure 8 - Tooth germ: early bell stage presenting the first band of dentin; large embryonic bone trabeculae forming the embryonic bone (Masson's trichrome staining, $\times 200)$.

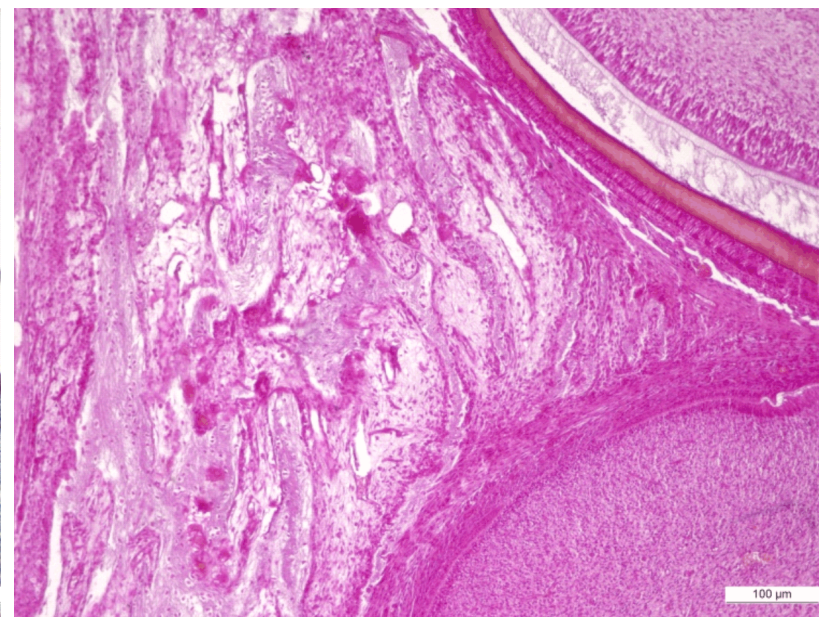

Figure 10 - Tooth germs: advanced bell stage, surrounded by the mesenchymal tissue characteristic of dental sacs and developing maxillary embryonic bone (PAS staining, ×100). PAS: Periodic Acid-Schiff.

allow a deeper insight into the prenatal craniofacial and tooth morphogenesis and a better comprehension of the formal development and reciprocal influences that govern this complex process.

In the last years, the understanding of these phenomena and events has been deepened, through targeted research at the cellular, molecular and gene levels. This translation was made possible due to the technical advances registered in the medical research, in parallel with the extension of experimental studies on developmental biology, in vivo and in vitro, by using animal models and cell lines [1, 3, $5,39-42]$. It is worth mentioning that the experimental approach is justified by the ethical consideration regarding the use of the human material $[43,44]$, their compliance limiting the research on human samples. Therefore, we consider of interest a brief overview of the gene and molecular substrate that govern the jaw and tooth development.

Recent data based on extended animal studies demonstrate the role of development genes and molecular pathways in the formation of jaw $[2,5]$, including the regulation 
of different stages in bone deposition. A first step in this process is the migration of the neural crests cells into the first pharyngeal arch, where none of the Hox genes is expressed $[5,45,46]$. In the body of mandible arch, the migration is regulated by the $O T X$ gene, transcription factors of the $M S X$ and $D L X$ families and several signaling factors [2]. After migration, the cells of neural crests originate chondroblasts and osteoblasts. The development of the basal and alveolar bone by intramembranous ossification starts around the Merkel's cartilage and is controlled by $M S X, D L X$ and GSC genes and signaling factors like bone morphogenetic proteins (BMPs) [2, 5-7].

The similarities and differences between the development of maxilla and mandible could be explained by the "hinge and caps" predictive model [47], based on the potential of different genes to influence different territories. Thus, Satb2 gene [32] and Six1 gene [48] coordinate the development of both maxilla and mandible, Endothelin 1 gene induces mandible identity [49], whereas $\mathrm{Nr} 2 \mathrm{f}$ nuclear receptor induces maxilla individuality [50], and Dlx5/6 gene expression is inhibited in mandible [51]. Nevertheless, the gene expression is strongly influenced by signaling pathways [i.e., Bmp, fibroblast growth factor (Fgf), Sonic hedgehog (Shh), Wnt pathways], their action being demonstrated in studies focused on the development of the mandible [52, 53].

Old and new concepts on tooth development are brought together in an excellent recent review [4] that offers an integrative insight in the early evolution of human dentition.

Experimental studies have demonstrated the role of epithelial-mesenchymal interactions in the initiation of tooth development. It is proven that tooth development is based on a mutually inductive molecular dialogue between the oral epithelium and the underlying mesenchyme [54, 55], dialogue in which the formation and degradation of dental basement membrane are important events [56]. These functional interrelations ripple through the process of tooth development, so that specific structural transformations, irrespective of the dentition type, remain identical.

Nowadays, the mechanisms involved in tooth development are analyzed by reference to genes, molecules and signaling cascades responsible for mediating or governing this process.

Tooth development is initiated by an orchestration of various genetic and epigenetic factors [1, 57-60]. The shape of the tooth is genetically determined through the homeobox genes [61]. These homeobox genes have been identified in mice; because mice do not have canines, the obtained code is considered "speculative"; however, there is a possible overlap of genes for a presumed canine region. Combinations of different expressions of homeobox genes could be: for incisors, $M S X-1, M S X-2$; for canines, $M S X-1$, $M S X-2, D L X-2$; for molars, $B A R X-1, D L X-2$ [62]. There are currently known approximately 300 tooth-related genes (i.e., Gli, Lef, Pax, Fgf, Msx, Dlx, Wht, Lhx, Bmp, Shh, Hgf, Ptc, Smo, Pitx, Slit, Barx, Otlx) and approximately 100 molecules (FGF8 and BMP4 are considered master molecules), which intervene in this complex process conjointly to the Shh and Wnt signaling pathways [1, 6 , 63-65]. Moreover, recent studies demonstrate the role of the stem cells that ensure the odontogenic potential for tooth development, with possible appliance in the tooth bioengineering research [66-69].

Nevertheless, according to existing data, no direct link has been identified between one gene and the ontogenesis of a specific tooth, most molecules do not act specifically at tooth level and the information of sent signal regulation is limited [61].

With respect to the national and international regulations imposed for the research performed on the human material resulting from abortion, the present study complements our previous works on this topic [9-12].

Despite the alone histological approach, our descriptive data sustained by valuable images can be added to the general repository of information on maxillary bone and tooth development.

Our study reveals early events in the embryonic bone and tooth germ formation. We illustrated the dynamics of the ossification stages, from stages of early-dispersed intramembranous ossification to the organization of the dental alveoli, incorporated step-by-step in the maxillary body, and the simultaneous presence of tooth germs with different sizes and shapes, in accordance with the development stage.

The most important aspects identified in our study target the intramembranous ossification model present in the maxillary bone. Microscopic examination revealed the beginning of bone development within the well-vascularized mesenchymal tissue, by condensing the proliferating mesenchymal cells into a "membrane-type" structure. As the vascularization increases in the areas of condensed mesenchyme, the mesenchymal cells were transformed into osteoblasts. The process was identified in multiple areas within the future intramembranous bone, the regions of initial osteogenesis representing primary ossification centers, in which bone spicules are formed. In relation to the gestational age, we were able to evaluate the formation of the embryonic bone by the progressive fusion of the bone spikes into thin plates or trabeculae, and the fusion of the plates to form a thicker, trabecular-type embryonic bone. It should be noted that the initial plates of intramembranous bone are structurally unstable, not only due to the random orientation of the fibers and the low degree of mineralization, but also because many islands of mesenchymal tissue, extremely loose, remain inside the plates. This embryonic bone (fibrillar, fibrous, or reticular), characteristic of the early embryo and fetus, is a nonlamellar bone. Morphologically, the dominant feature is conferred by the coarse collagen fibers that interlay or intersect to form a meshwork, which is why it is also called "woven bone". It is richer in cells, which are randomly placed, and the matrix has more ground substance than the mature bone.

In parallel, the microscopic traits characteristic for the developing tooth germs allow the correlation of the histological features with the evolution in relation to the 
gestational age. A noteworthy element is the adaptability of the tooth germs to the intraosseous localization, by the variability of size and shape in accordance with the stage of development and the type of tooth. The cellular complexity of the enamel organ epithelia ensures the synthesis and deposition of the enamel, whereas the differentiation of the odontoblasts ensures the synthesis and deposition of dentin. However, the histological architecture of these structures, easily recognizable by light microscopy, concentrates a complex molecular substrate.

From this perspective, the present paper should be considered a preliminary report. As a perspective, the used human material has the potential to be exploited by extending the study on the molecular mechanisms involved in maxillary bone and tooth development.

Last but not least, we reiterated an assertion formulated in a previous paper [9] regarding the small number of available images illustrating the maxillary bone and tooth development stages in humans [25-27, 33-38], because of the ethical and technical impediments in accessing suitable material $[9,44]$. Therefore, in addition to our already published data [9], we consider our results an important contribution for the enlargement of existing visual information for maxillary bone and tooth development.

\section{ㅁ Conclusions}

Although the morphological stages of tooth development, in parallel with maxillary bone construction, are known for decades, the interest in the knowledge of these events at the molecular level is still current, aiming to sustain the progress in the endorsement of novel regenerative and restorative therapies. Nowadays, the mechanisms involved in the maxillary bone and tooth development are studied mainly by using experimental models. Therefore, a study conducted on human material, respecting the ethical regulations of the research, maintains its value. Our study complements the existing data regarding the embryonic period, by identification of the morphological elements, which characterize the early stages of the maxillary alveolar bone and tooth development.

\section{Conflict of interests}

The authors declare that they have no conflict of interests.

\section{References}

[1] Koussoulakou DS, Margaritis LH, Koussoulakos SL. A curriculum vitae of teeth: evolution, generation, regeneration. Int J Biol Sci, 2009, 5(3):226-243. https://doi.org/10.7150/ijbs.5.226 PMID: 19266065 PMCID: PMC2651620

[2] Benoît R. Development of the human mandible under the influence of the environment and/or genetics. J Dentofacial Anom Orthod, 2012, 15(1):106. https://doi.org/10.1051/odfen/ 2011406

[3] Alfaqeeh SA, Gaete M, Tucker AS. Interactions of the tooth and bone during development. J Dent Res, 2013, 92(12): 1129-1135. https://doi.org/10.1177/0022034513510321 PMID: 24155263

[4] Hovorakova M, Lesot H, Peterka M, Peterkova R. Early development of the human dentition revisited. J Anat, 2018 233(2):135-145. https://doi.org/10.1111/joa.12825 PMID: 29745448 PMCID: PMC6036925
[5] Yuan $Y$, Chai $Y$. Regulatory mechanisms of jaw bone and tooth development. Curr Top Dev Biol, 2019, 133:91-118. https://doi.org/10.1016/bs.ctdb.2018.12.013 PMID: 30902260 PMCID: PMC6986348

[6] Nanci A. Ten Cate's oral histology: development, structure, and function. $9^{\text {th }}$ edition, Elsevier, St. Louis, Missouri, USA, 2017.

[7] Sadler TW. Langman's medical embryology. $14^{\text {th }}$ edition, Wolters Kluwer, Philadelphia, USA, 2019.

[8] Lesot $\mathrm{H}$, Brook $\mathrm{AH}$. Epithelial histogenesis during tooth development. Arch Oral Biol, 2009, 54(Suppl 1):S25-S33. https:// doi.org/10.1016/j.archoralbio.2008.05.019 PMID: 18656852

[9] Săvinescu SD, Dănilă V, Trandafirescu M, Căruntu ID. Correlations between morphology and evolution in the structure of the tooth germ. Oral Health Dent Manag, 2011, 10(3):143-151.

[10] Săvinescu DS. Investigaţie morfologică complexă în dezvoltarea sistemului stomatognat. Teză de doctorat, Universitatea de Medicină şi Farmacie "Grigore T. Popa", laşi, 2013 (in Romanian).

[11] Caruntu ID, Savinescu SD, Lozneanu L, Balan R, Amalinei C, Giusca SE. Similarities and differences of cyclin D1 expression in tooth germ development. Virchows Arch, 2019, 475(Suppl 1): 357. https://doi.org/10.1007/s00428-019-02631-8

[12] Caruntu ID, Savinescu SD, Lozneanu L, Amalinei C, Balan R, Giusca SE. PS-09-067: MMP-9 and TIMP-1 expression in tooth development. Virchows Arch, 2017, 471(1 Suppl):S159. https://doi.org/10.1007/s00428-017-2205-0

[13] Röse C. Über die Entwicklung der Zähne des Menschen. Arch Mikrosk Anat, 1891, 38(1):447-491. https://doi.org/10. 1007/BF02954397

[14] Leche W. Nachträge zu Studien über die Entwicklung des Zahnsystems bei den Säugethieren. Morphol Jahrb, 1893, 20:113-142.

[15] Röse C. Überreste einer vorzeitigen Prälactealen und einer vierten Zahnreihe beim Menschen. Österung Vierteljahrschr Zahnheilk, 1895, 11:45-50.

[16] Dependorf. Zur Frage der überzähligen Zähne im menschlichen Gebiß. Z Morphol Anthropol, 1907, 10(2):171-196.

[17] Adloff P. Überreste einer prälaktealen Zahnreihe beim Menschen. Dtsch Mschr Zahnheilk, 1909, 27:828-832.

[18] Ahrens H. Die Entwicklung der menschlichen Zähne. Anat Hefte, 1913, 48(2):167-266. https://doi.org/10.1007/BF0211 6170

[19] Bolk L. Odontological essays. First essay: On the development of the palate and alveolar ridge in man. J Anat, 1921, 55(Pt 2-3): 138-152. PMID: 17103920 PMCID: PMC1262920

[20] Schour I. Early human tooth development, with special reference to the relationship between the dental lamina and the lipfurrow band. J Dent Res, 1929, 9(5):699-717. https://doi.org/ 10.1177/00220345290090050801

[21] Logan WHG, Kronfeld R. Development of the human jaws and surrounding structures from birth to the age of fifteen years. J Am Dent Assoc, 1933, 20(3):379-427.

[22] Kronfeld R. Development and calcification of the human deciduous and permanent dentition. Bur, 1935, 35(1):18-25.

[23] Logan WHG. A histologic study of the anatomic structures forming the oral cavity. J Am Dent Assoc, 1935, 22(1):3-30.

[24] Schour I, Massler M. The development of the human dentition. J Am Dent Assoc, 1941, 28(7):1153-1160.

[25] Merida-Velasco JA, Sanchez-Montesinos I, Espin-Ferra J, Garcia-Garcia JD, Roldan-Schilling V. Developmental differences in the ossification process of the human corpus and ramus mandibulae. Anat Rec, 1993, 235(2):319-324. https://doi.org/ 10.1002/ar.1092350216 PMID: 8420400

[26] Rodríguez-Vázquez JF, Mérida-Velasco JR, Arráez-Aybar LA, Jiménez-Collado J. A duplicated Meckel's cartilage in a human fetus. Anat Embryol (Berl), 1997, 195(6):497-502. https://doi. org/10.1007/s004290050069 PMID: 9193724

[27] Mérida Velasco JR, Rodríguez Vázquez JF, De la Cuadra Blanco C, Campos López R, Sánchez M, Mérida Velasco JA. Development of the mandibular condylar cartilage in human specimens of 10-15 weeks' gestation. J Anat, 2009, 214(1): 56-64. https://doi.org/10.1111/j.1469-7580.2008.01009.x PMID: 19166473 PMCID: PMC2667917

[28] Varo Poyatos A, Merida Velasco JA, Espin Ferra J. [Growth of first molars]. Rev Actual Estomatol Esp, 1988, 48(373):7576, 79-80, 83-84 passim. PMID: 3253824 
[29] Rodriguez Vazquez JF, Merida Velasco JR, Sanz Casado JV, Badanelli Marcano P. [The development of the dental crest in the upper maxillary arch]. Rev Actual Estomatol Esp, 1988, 48(372):75-81. PMID: 3253821

[30] Orliaguet T, Déchelotte P, Scheye T, Vanneuville G. The relationship between Meckel's cartilage and the development of the human fetal mandible. Surg Radiol Anat, 1993, 15(2): 113-118. https://doi.org/10.1007/BF01628309

[31] Orliaguet T, Darcha C, Déchelotte P, Vanneuville G. Meckel's cartilage in the human embryo and fetus. Anat Rec, 1994 238(4):491-497. https://doi.org/10.1002/ar.1092380408 PMID: 8192246

[32] Wyganowska-Świątkowska M, Przystańska A. The Meckel's cartilage in human embryonic and early fetal periods. Anat Sci Int, 2011, 86(2):98-107. https://doi.org/10.1007/s12565010-0093-3 PMID: 20799009

[33] Radlanski RJ, Kubein-Meesenburg D. [Embryologic studies on the development of tooth form]. Dtsch Zahnarztl Z, 1990, 45(7 Spec No):S58-S60. PMID: 2269155

[34] Radlanski RJ. Morphogenesis of human tooth primordia: the importance of 3D computer-assisted reconstruction. Int J Dev Biol, 1995, 39(1):249-256. PMID: 7626413

[35] Radlanski RJ, van der Linden FP, Ohnesorge I. 4D-computerized visualisation of human craniofacial skeletal growth and of the development of the dentition. Ann Anat, 1999, 181(1):3-8. https:// doi.org/10.1016/S0940-9602(99)80076-4 PMID: 10081550

[36] Radlanski RJ, Renz H. A possible interdependency between the wavy path of enamel rods, distances of Retzius lines, and mitotic activity at the cervical loop in human teeth: a hypothesis. Med Hypotheses, 2004, 62(6):945-949. https://doi.org/10.10 16/j.mehy.2003.12.038 PMID: 15142654

[37] Radlanski RJ, Renz H, Zimmermann CA, Schuster FP, Voigt A Heikinheimo K. Chondral ossification centers next to denta primordia in the human mandible: a study of the prenatal development ranging between 68 to $270 \mathrm{~mm}$ CRL. Ann Anat, 2016, 208:49-57. https://doi.org/10.1016/j.aanat.2016.07.006 PMID: 27497714

[38] Radlanski RJ, Renz H, Tsengelsaikhan N, Schuster F, Zimmermann CA. The remodeling pattern of human mandibular alveolar bone during prenatal formation from 19 to $270 \mathrm{~mm}$ CRL. Ann Anat, 2016, 205:65-74. https://doi.org/10.1016/j. aanat.2016.01.005 PMID: 26921449

[39] Thesleff I. The genetic basis of tooth development and dental defects. Am J Med Genet A, 2006, 140(23):2530-2535. https:// doi.org/10.1002/ajmg.a.31360 PMID: 16838332

[40] Townsend G, Harris EF, Lesot H, Clauss F, Brook A. Morphogenetic fields within the human dentition: a new, clinically relevant synthesis of an old concept. Arch Oral Biol, 2009 54(Suppl 1):S34-S44. https://doi.org/10.1016/j.archoralbio. 2008.06.011 PMID: 18760768 PMCID: PMC2981872

[41] Balic A. Biology explaining tooth repair and regeneration: a mini-review. Gerontology, 2018, 64(4):382-388. https://doi. org/10.1159/000486592 PMID: 29533942

[42] Yamada S, Lav R, Li J, Tucker AS, Green JBA. Molar budto-cap transition is proliferation independent. J Dent Res, 2019, 98(11):1253-1261. https://doi.org/10.1177/002203451 9869307 PMID: 31393749 PMCID: PMC6761786

43] American Academy of Pediatrics. Committee on Pediatric Research and Committee on Bioethics. Human embryo research. Pediatrics, 2001, 108(3):813-816. https://doi.org/ 10.1542/peds.108.3.813 PMID: 11533357

[44] Săvinescu SD, Sfrijan R, Căruntu ID, Grigoraş A. Human embryo research - from necessity to ethical implications: the study of developing tooth germ. Rev Rom Bioet, 2012, 10(1):67-78 (in Romanian), 149-160 (in English).

[45] Leucht P, Kim JB, Amasha R, James AW, Girod S, Helms JA Embryonic origin and Hox status determine progenitor cell fate during adult bone regeneration. Development, 2008, 135(7):2845-2854. https://doi.org/10.1242/dev.023788 PMID: 18653558

[46] Chung IH, Yamaza T, Zhao H, Choung PH, Shi S, Chai Y. Stem cell property of postmigratory cranial neural crest cells and their utility in alveolar bone regeneration and tooth development. Stem Cells, 2009, 27(4):866-877. https://doi. org/10.1002/stem.2 PMID: 19350689 PMCID: PMC2896558

[47] Depew MJ, Compagnucci C. Tweaking the hinge and caps: testing a model of the organization of jaws. J Exp Zool B Mol
Dev Evol, 2008, 310B(4):315-335. https://doi.org/10.1002/jez. b.21205 PMID: 18027841

[48] Tavares ALP, Cox TC, Maxson RM, Ford HL, Clouthier DE. Negative regulation of endothelin signaling by $S I X 1$ is required for proper maxillary development. Development, 2017, 144(11): 2021-2031. https://doi.org/10.1242/dev.145144 PMID: 28455376 PMCID: PMC5482985

[49] Sato T, Kurihara Y, Asai R, Kawamura Y, Tonami K, Uchijima Y, Heude E, Ekker M, Levi G, Kurihara H. An endothelin-1 switch specifies maxillomandibular identity. Proc Natl Acad Sci U S A, 2008, 105(48):18806-18811. https://doi.org/10.1073/pnas.08 07345105 PMID: 19017795 PMCID: PMC2596216

[50] Barske L, Rataud P, Behizad K, Del Rio L, Cox SG, Crump JG. Essential role of $\mathrm{Nr} 2 \mathrm{f}$ nuclear receptors in patterning the vertebrate upper jaw. Dev Cell, 2018, 44(3):337-347.e5. https://doi.org/10.1016/j.devcel.2017.12.022 PMID: 29358039 PMCID: PMC5801120

[51] Ruest LB, Xiang X, Lim KC, Levi G, Clouthier DE. Endothelin-A receptor-dependent and -independent signaling pathways in establishing mandibular identity. Development, 2004, 131(18): 4413-4423. https://doi.org/10.1242/dev.01291 PMID: 15306564 PMCID: PMC2818681

[52] Jin YR, Turcotte TJ, Crocker AL, Han XH, Yoon JK. The canonical Wnt signaling activator, R-spondin2, regulates craniofacial patterning and morphogenesis within the branchial arch through ectodermal-mesenchymal interaction. Dev Biol, 2011, 352(1):1-13. https://doi.org/10.1016/j.ydbio.2011.01.004 PMID: 21237142 PMCID: PMC3089906

[53] Li F, Fu G, Liu Y, Miao X, Li Y, Yang X, Zhang X, Yu D, Gan L, Qiu M, Chen Y, Zhang Z, Zhang Z. ISLET1-dependent $\beta$ catenin/hedgehog signaling is required for outgrowth of the lower jaw. Mol Cell Biol, 2017, 37(8):e00590-16. https://doi. org/10.1128/MCB.00590-16 PMID: 28069742 PMCID: PMC 5376631

[54] Jernvall J, Keränen SVE, Thesleff I. Evolutionary modification of development in mammalian teeth: quantifying gene expression patterns and topography. Proc Natl Acad Sci U S A, 2000, 97(26):14444-14448. https://doi.org/10.1073/pnas.97.26.14444 PMID: 11121045 PMCID: PMC18938

[55] Pispa J, Thesleff I. Mechanisms of ectodermal organogenesis. Dev Biol, 2003, 262(2):195-205. https://doi.org/10.1016/s00 12-1606(03)00325-7 PMID: 14550785

[56] Heikinheimo K, Salo T. Expression of basement membrane type IV collagen and type IV collagenases (MMP-2 and MMP-9) in human fetal teeth. J Dent Res, 1995, 74(5):1226-1234. https:// doi.org/10.1177/00220345950740051301 PMID: 7790601

[57] Tonge $\mathrm{CH}$. Identification of cell patterns in human tooth differentiation. J Dent Res, 1967, 46(5):876-878. https://doi.org/10. 1177/00220345670460054401 PMID: 5234028

[58] Tonge $\mathrm{CH}$. The time-structure relationship of tooth development in human embryogenesis. J Dent Res, 1969, 48(5):745-752. https://doi.org/10.1177/00220345690480052301 PMID: 5259412

[59] Jernvall J, Thesleff I. Reiterative signaling and patterning during mammalian tooth morphogenesis. Mech Dev, 2000, 92(1):19-29. https://doi.org/10.1016/s0925-4773(99)00322-6 PMID: 10704885

[60] Hovorakova M, Lesot $H$, Peterka M, Peterkova R. The developmental relationship between the deciduous dentition and the oral vestibule in human embryos. Anat Embryol (Berl), 2005, 209(4):303-313. https://doi.org/10.1007/s00429-0040441-y PMID: 15666156

[61] Tucker AS, Sharpe PT. Molecular genetics of tooth morphogenesis and patterning: the right shape in the right place. J Dent Res, 1999, 78(4):826-834. https://doi.org/10.1177/00 220345990780040201 PMID: 10326726

[62] Thomas BL, Sharpe PT. Patterning of the murine dentition by homeobox genes. Eur J Oral Sci, 1998, 106(Suppl 1):48-54. https://doi.org/10.1111/j.1600-0722.1998.tb02153.x PMID: 9541203

[63] Helder MN, Karg H, Bervoets TJ, Vukicevic S, Burger EH, D'Souza RN, Wöltgens JH, Karsenty G, Bronckers AL. Bone morphogenetic protein-7 (osteogenic protein-1, OP-1) and tooth development. J Dent Res, 1998, 77(4):545-554. https:// doi.org/10.1177/00220345980770040701 PMID: 9539457

[64] Zhou Y, Zheng L, Li F, Wan M, Fan Y, Zhou X, Du W, Pi C, Cui D, Zhang B, Sun J, Zhou X. Bivalent histone codes on WNT5A during odontogenic differentiation. J Dent Res, 2018, 
97(1):99-107. https://doi.org/10.1177/0022034517728910 PMID: 28880717

[65] Xiong $\mathrm{Y}$, Fang $\mathrm{Y}$, Qian $\mathrm{Y}$, Liu $\mathrm{Y}$, Yang $\mathrm{X}$, Huang $\mathrm{H}$, Huang $\mathrm{H}$, Li Y, Zhang X, Zhang Z, Dong M, Qiu M, Zhu XJ, Zhang Z. Wnt production in dental epithelium is crucial for tooth differentiation. J Dent Res, 2019, 98(5):580-588. https://doi.org/ 10.1177/0022034519835194 PMID: 30894046

[66] Hu X, Lin C, Shen B, Ruan N, Guan Z, Chen Y, Zhang Y. Conserved odontogenic potential in embryonic dental tissues. J Dent Res, 2014, 93(5):490-495. https://doi.org/10.1177/ 0022034514523988 PMID: 24554539
[67] Zhang Y, Chen YP. Bioengineering of a human whole tooth: progress and challenge. Cell Regen (Lond), 2014, 3(1):8. https://doi.org/10.1186/2045-9769-3-8 PMID: 25408887 PMCID: PMC4230350

[68] Thesleff I. From understanding tooth development to bioengineering of teeth. Eur J Oral Sci, 2018, 126(Suppl 1):67-71. https://doi.org/10.1111/eos.12421 PMID: 30178557

[69] Yelick PC, Sharpe PT. Tooth bioengineering and regenerative dentistry. J Dent Res, 2019, 98(11):1173-1182. https://doi. org/10.1177/0022034519861903 PMID: 31538866 PMCID: PMC7315683

\section{Corresponding author}

Simona Eliza Giuşcă, Lecturer, MD, PhD, Department of Morphofunctional Sciences I - Pathology, Grigore T. Popa University of Medicine and Pharmacy, 16 University Street, 700115 laşi, Romania; Phone +40758-383 773, e-mails: simonaelizagiusca@gmail.com, simona-eliza.giusca@umfiasi.ro

Received: January 28, 2020

Accepted: July 21, 2020 